\title{
Correction: In the race for knowledge, is human capital the most essential element?
}

\author{
Laura Sinay (D), Rodney William (Bill) Carter \& Maria Cristina Fogliatti de Sinay
}

Correction to: Humanities and Social Sciences Communications https://doi.org/10.1057/s41599-020-0521-5, published online 08 July 2020.

The original version of the paper included mistakes in the reference list.

All online references in the original version of this paper were stated as being accessed in 2020; however, they were actually accessed in 2019.

These dates have now been corrected in both the online and PDF article file.

Published online: 28 August 2020

Open Access This article is licensed under a Creative Commons Attribution 4.0 International License, which permits use, sharing, adaptation, distribution and reproduction in any medium or format, as long as you give appropriate credit to the original author(s) and the source, provide a link to the Creative Commons license,
and indicate if changes were made. The images or other third party material in this article are included in the article's Creative Commons license, unless indicated otherwise in a credit line to the material. If material is not included in the article's Creative Commons license and your intended use is not permitted by statutory regulation or exceeds the permitted use, you will need to obtain permission directly from the copyright holder. To view a copy of this license, visit http://creativecommons.org/licenses/by/4.0/.

(c) The Author(s) 2020 